\title{
Alienated Politics: Labour Insurgency and the Paternalistic State in China
}

\author{
Eli Friedman \\ Cornell University
}

\begin{abstract}
Is there a labour movement in China? This contribution argues that China does not have a labour movement, but that contestation between workers, state and capital is best characterized as a form of 'alienated politics'. Widespread worker resistance is highly effective at the level of the firm because of its ability to inflict losses on capital and disrupt public order. But authoritarian politics in China prevent workers from formulating political demands. Despite the spectacular repressive capacity of the state, the central government has in fact responded to highly localized resistance by passing generally pro-labour legislation over the past decade. The consequence of this is that worker unrest has produced important political shifts at the national level, but these have come about without workers' direct involvement in the process. In other words, workers are alienated from the political object that they themselves have produced. As a consequence, when the state intervenes in labour politics, it appears to be doing so of its own accord, i.e. paternalistically. This framework helps us to understand how worker unrest in China has become highly antagonistic towards employers and the local state, while maintaining the stability of the system as a whole.
\end{abstract}




\section{INTRODUCTION}

Are labour movements a twentieth century phenomenon, now relegated to the status of historical also-ran? As was discussed in the 2013 Forum issue of Development and Change, there has been a major upsurge in global activism since 2010. It was clear in Kees Biekart and Alan Fowler's (2013) Introduction to the Debate section on 'Activisms $2010+^{\prime}$, that traditional labour movements - in which formal unions mobilize membership in making political and economic demands on state and capital - have been notably absent in this upsurge. Given increasing inequality, unemployment and precarity of work globally, this absence cannot be explained by workers' satisfaction with their current lot. While the social, cultural, economic and political factors that have resulted in the seeming terminal decline of twentieth century labour institutions are complex, it is beyond doubt that the labour movement in the global North is a shadow of its former self. If we were to look for signs of an emergent labour movement today, we might reasonably look to the world's most dynamic centre of capital accumulation over the past generation - The People's Republic of China.

Is there a labour movement in China? One common perspective - and the one we are most frequently exposed to in the West - leads to quite pessimistic conclusions. Chinese workers are brutally exploited as they are subject to long hours, low pay, monotonous work, while being denied basic political rights such as freedom of association, the right to strike and collective bargaining rights. In recent years, the inability of the Chinese working class to act collectively has come to be symbolized by the worker suicides at Foxconn (J. Chan and Pun, 2010; 
Pun and J.W. Chan, 2012). In a situation in which collective voice is not possible, high turnover rates and labour shortages have become endemic in Chinese industry as workers choose the individualized 'exit' option. When workers do protest collectively, it almost never extends beyond a single workplace; to do otherwise incites harsh state repression.

On the other hand, Beverly Silver and Lu Zhang (2009) have referred to China as the 'epicenter of global labor unrest', and China currently has more strikes than any other country in the world. Despite having no right to strike, workers who walk off the job are likely to win many of their demands and regularly gain double-digit salary increases. Although there are no independent unions or political parties and workers view the official All-China Federation of Trade Unions (ACFTU) as illegitimate, there have been major policy changes. Minimum wages around the country are finally outpacing inflation, social spending has increased rapidly for more than a decade, and the central government has enacted a raft of new legislation intended to help workers. Which is it: are workers hopelessly atomized or is a powerful labour movement emerging? As posed in the Introduction to this Debate section, are worker struggles merely defensive in nature? And what has been the role of the state in responding to increased labour conflict?

In this contribution I suggest that labour politics in contemporary China are best characterized as a form of 'alienated politics'. Worker resistance is rational at the level of the firm (e.g. demands for higher wages), but when aggregated at the class level, tens of thousands of incidents of protest appear irrational in that they pose no political 
demands (e.g. right to strike, independent unions, social welfare). And yet, given the real threat to social stability posed by ongoing cellularized worker insurgency, the state must respond to this 'irrational' bargaining partner. Over the last decade, the central government has enacted a series of pro-labour policies and pieces of legislation with the hopes of ameliorating class conflict. Thus, worker resistance is political and does have major consequences - but it is alienated in the sense that workers themselves are not able to participate in politics at the class level. The consequence of this is that when the state enacts pro-labour legislation unilaterally, and seemingly of its own accord, it appears to be doing so paternalistically rather than in response to a specifically articulated demand. This helps us to account for the stability of the system even while workers have become increasingly antagonistic towards employers and local governments.

This perspective provides greater analytical clarity than is possible with the popular 'corporatist' framework. More than twenty years ago, Anita Chan (1993) inquired as to whether the future of Chinese labour politics was 'revolution or corporatism'. While the question as originally posed helped to illuminate important conditions at the time, neither of these outcomes has come to pass. Even the more specific sub-variety of 'state corporatism', in which governmentdominated representative bodies incorporate the working class in a nondemocratic manner, cannot account for contemporary dynamics. Expansive worker unrest is testament to the illusory (Ost, 2000) nature of Chinese corporatism: even if official unions claim to speak on behalf of workers, these representatives have not in any meaningful sense 
incorporated the working class into legalized and rationalized channels of contention. Alienated politics allows us to move beyond an anticipation of incorporation to explain current patterns of insurgent resistance at the local level as well as elite-level responses.

Although there is no labour movement in China, workers have not been passive. And their resistance - sporadic, ephemeral and limited in scope though it may be - has had major political consequences. In light of increasing worker unrest for two decades, how is it that the state has been able to 'alienate' politics and keep the new working class so cellularized? Certainly brute force has played a role, but repression has developed in more nuanced ways as well.

\section{DEPOLITICIZATION}

As argued by Wang Hui $(2006,2009)$, depoliticization has been a key project of the Chinese state. Partially in response to the very real trauma that many people experienced during the Cultural Revolution, the Party has insisted on pragmatism in the reform era. Politically, this has resulted in the state using its symbolic power to de-emphasize class categories, in many ways paralleling similar patterns of enhanced individualization occurring in the West (Beck, 1992; Yan, 2010). Some Chinese scholars have argued that the state and academy have bid 'farewell' to class (Guo, 2009), and that class discourse has been 'subsumed' (Pun and C.K.-C. Chan, 2008). ${ }^{1}$ 
Individualization of conflict has not merely proceeded at the symbolic level. Rather, the state has taken concrete administrative steps to prevent aggrieved workers from linking up. The shift from the social contract, which undergirded the system of labour relations in the command economy, and its replacement by a legal contract is essential in the individualization of conflict (Friedman and Lee, 2010). Similarly, Feng Chen (2007) has argued that the state has endowed workers with a growing array of individual rights but that such seeming advances are undermined by the continual absence of collective rights, namely the right to organize and strike. When workers try to file collective grievances through the legal system, courts seek to break them up into a series of individual cases (F. Chen and $X u, 2012)$. While not specific to labour grievances, the state has developed an advanced set of techniques for engaging and defusing potential troublemakers at the local level (Lee and Zhang, 2013).

In addition, the state has continued to coercively enforce the ACFTU's monopoly on working class representation. A deeply conservative organization, the official union federation is tightly controlled by the state from the central to the local level (F. Chen, 2009), and is generally controlled by management within the enterprise. Unions remain reactive to strikes, and they are legally required to encourage workers to re-establish production as soon as possible in the event of a work stoppage. Although the ACFTU has played an important role in pushing for legal reform at the national level, it is likely either to side 
with management or serve as an intermediary in the case of labour conflict at the enterprise level (F. Chen, 2010; Friedman, 2012). Unions are sometimes amenable to pushing for economic demands within the enterprise, but they work in coordination with the state's repressive apparatus to ensure that worker unrest does not extend beyond a single workplace. Workers have occasionally demanded democratic elections for enterprise-level union representatives, but any attempt to establish formally independent organizations will be met with harsh state repression.

Even if these techniques have restricted worker unrest to particular workplaces, labour conflicts have nonetheless caused major disruptions. In response to this the state has massively expanded its repressive capacity (though it should be noted that labour unrest is just one of the many sources of instability). Much of the military's attention and resources have been directed towards enhancing 'non-combat operations' - i.e. preparing for domestic rather than foreign threats (Fravel, 2011). So-called 'stability-maintenance' committees have been set up at all levels of the state (X. Chen, 2013), and by 2012 the government was spending nearly 5 per cent more on internal security than it was on national defence (Buckley, 2012). Additionally, social stability has come to be an important criterion in government officials' performance evaluations (Zhu, 2011).

\section{DEATH OF ONE CLASS - BIRTH OF ANOTHER?}

During the state socialist period, urban workers in state-owned enterprises were a privileged class. While they were subject to intensive 
control, the work unit also provided generous welfare benefits known as the 'iron rice bowl'. But beginning in the late 1990s, the government encouraged massive layoffs (Solinger, 2001), privatization (Solinger, 2009), and reductions in benefits in order to make the remaining enterprises competitive in the market (Gallagher, 2005). Although the former 'leading class' suffered immensely in this process, they did not go down without a fight, and the late 1990s and early 2000s witnessed a major upsurge in protest (Hurst, 2009; Lee, 2002). While such protests over privatization or theft of pensions among state-sector workers still occur occasionally, they have largely subsided in recent years.

Emerging from an entirely different social universe, a new class of migrant workers began to appear in urban China in the 1980s and 1990s. The emergence of this class has fundamentally altered all aspects of social life domestically, while allowing for a major reconfiguration of supply chains globally. Now numbering more than 250 million, these workers are internal migrants who have left the countryside for the city. In doing so, they forsake their right to access social goods such as healthcare, education and pensions. In China, the hukou system of household registration ties the provision of such services to place, such that if you leave your place of registration you are guaranteed nothing (K.W. Chan, 2009). ${ }^{2}$ While there are major differences with undocumented immigrants in Western countries, there are important parallels in terms of their economic and political pre- carity. Primary

2 There is some debate about the continuing relevance of the hukou system, with Shaohua Zhan (2011) suggesting it is not so important in determining life chances, while Kam Wing Chan sees it as an ongoing obstacle to migrant integration (K.W. Chan, 2010; K.W. Chan and Buckingham, 2008). 
grievances that migrants have experienced include low pay, nonpayment of wages, long hours, dangerous working conditions, abusive management and non-payment of social insurance.

Ching Kwan Lee (2007) has produced the definitive account of worker protest in reform-era China. Following Beverly Silver, she has referred to the defensive protest that attends the unmaking of a class (among state- sector workers) as Polanyi-style protest. This is because these workers were in a highly protected and decommodified form of employment, and were subsequently thrust into a situation in which they had to secure livelihood through the market. Lee refers to resistance among migrants as Marx-style protest, as it occurs during the process of class formation.

Indeed, a Marxist perspective (broadly speaking) is immensely useful in understanding the politics of the particularly raw form of capitalist labour relations that emerged in China's industries in the reform era. Migrant worker unrest looks quite similar to the first stage of the Communist Manifesto teleology, in which workers are engaged in militant struggles against particular capitalists, but have not yet articulated a class politics. But Marx's power of prediction for the China case quickly shows its limits, as he argues, 'The real fruit of their battles lies, not in the immediate result, but in the ever expanding union of the workers' (Marx, 1994: 166). The various strategies mentioned above have thus far prevented anything that looks like an 'ever expanding union' from emerging.

Nonetheless, some scholars remain relatively sanguine about the 
development of class politics in China. In particular, Pun Ngai and Chris Chan have argued that migrant workers are a class in formation, and that they have become more consciously antagonistic to capital (C.K.-C. Chan, 2010, 2012; C.K.-C. Chan and Pun, 2009). This line of argumentation echoes - though not explicitly - theorization associated with operaismo, which sees direct confrontation in the workplace and wage demands as potentially revolutionary activity. From this perspective, 'the workers become, from the first, "a class for itself' - that is, from the first moments of direct confrontation with the individual employer' (Tronti, 1971), and the fact that such activity is divorced from a grand political agenda is not seen as a sign of weakness. Regardless of one's analysis of the situation, there is scholarly unanimity that migrant worker resistance in China has remained fractured and ephemeral. Even if workers frequently win immediate demands directed at their employers, they have not built up sustainable political organization.

Given limited space, I can only provide a couple of recent examples to illustrate these dynamics. For many years, a lawless legal environment resulted in a prevalence of rights-based demands among Chinese workers. As just one recent example, in August 2013, workers from the Xinrongxin Kitchen Appliance Company went on strike to demand four months of back wages (totaling RMB 4 million). ${ }^{3}$ On the morning of 27 August, they began a public march with signs demanding their back wages. During the ensuing confrontation with the police, the twelve-year-old daughter of one of the workers was beaten over the head by a police officer. Although the outcome of this case was not 
reported, it is common for workers to receive some, if not all, of their owed wages in such cases. If enterprise managers flee - not an uncommon occurrence - the local government will often provide some compensation to prevent further unrest.

In recent years interest-based demands have become more common in China, a turning point marked symbolically by the 2010 strike wave sparked by workers atNanhai Honda (Friedman, 2013; see also C.K.-C. Chan, 2014). Two years later, a similar strike occurred at the jointventure Youde Auto, an electrical parts supplier in Wuhan. ${ }^{4}$ Wages at Youde were originally RMB 1,100, exactly the minimum wage for Wuhan. Upset with such low pay, more than 1,000 workers at the plant went on strike demanding a RMB 500 wage hike. As is common in most strikes, workers did not trust the management- controlled union to represent them, but they were also reluctant to choose their own representatives for fear of reprisals. Management's first two offers were well below what workers were demanding. Eventually the strike ended when workers agreed to a RMB 200 wage rise - far short of their original demand, but still a nearly 20 per cent increase over existing wages.

Even in the case of regularly occurring strike waves, there is little interworkplace coordination, and sustainable political organization does not develop. One clear example of this phenomenon comes from the sanitation sector in Guangzhou, which has experienced successive strikes since 2008 (Friedman, 2014). After the first strike in Baiyun district in 2008 , the official Guangzhou Federation of Trade Unions attempted to 
establish a sectoral union to raise standards for employees in the hundreds of privately-owned sanitation companies that were responsible for street sweeping and garbage collection. But this attempt by the government-controlled union federation failed, and workers in other districts went on strike in 2010 and early 2012 to demand higher wages. In late 2012 and early 2013, there was a massive strike wave involving thousands of workers in nearly every district of the city. This activity was not centrally coordinated, but rather consisted of copycat strikes in which workers at various private companies all shared common grievances of low wages and long hours. The government eventually intervened, promising to devote hundreds of millions of yuan to increase salaries for sanitation workers, and to establish strict industry-wide standards. However, sustainable and independent inter-workplace organization did not result from the strike wave. As workers remain isolated from each other, enforcement of new standards remains a serious concern.

There have occasionally been moments in which some space opened for civil society participation in worker organizing. One notable recent case is the campaign around the imprisonment of Wu Guijun. This case began in May 2013, when workers at a factory owned by Diweixin went on strike. The factory was shutting down and the workers had been in ongoing negotiations over their severance. Approximately two weeks into the strike, a number of workers were arrested while protesting among them Wu Guijun, a worker-selected representative. Although the other workers were released relatively quickly, Wu was kept in detention. In mid-September, the case began to be publicized on Weibo 
(China's Twitter-equivalent), with people around the country demanding Wu's release and rallying around the slogan, 'Striking is not a crime'.

Despite involvement from civil society organizations in Mainland China, Hong Kong and overseas, Wu remains imprisoned. At the time of writing, his court date has just been announced, and labour activists will be watching the results closely. This is the most explicitly political example of labour activism that has occurred within China in recent memory. While the outcome - both for Wu personally, and more broadly speaking - is still not clear, this represents a significant development.

While Chinese worker activism has not cohered into an organized and politicized force, it has - as already mentioned - caused major economic and social disruption. While it is impossible to state with any confidence precisely how many strikes and worker protests occur in China (such official numbers are a state secret), there are certainly thousands if not tens of thousands of such incidents every year. ${ }^{5}$ Although the central state has thus far failed to reduce worker insurgency, it is not for lack of effort.

\section{A DOUBLE MOVEMENT IN CHINA?}

In recent years, scholars have written extensively on the Chinese state's ability to maintain authoritarian power despite growing differentiation in the economy and society. This durability has been attributed to a number of factors - rationalization of decision-making

5 Until 2005, the government released statistics for the number of 'mass incidents', events in which twenty-five or more people engage in some form of public demonstration. Unofficial estimates put the total number of mass incidents at 180,000 for 2010. It is unknown what percentage is labour-related, but most scholars agree that labour, land and environmental issues are the largest sources of unrest. 
processes (Nathan, 2003), reinvention of the 'revolutionary heritage' (Perry, 2007:7), elite cohesion, and capacity to integrate emergent groups (Dickson, 2003; Wright, 2010), among other factors.

However, it is also evident that the state has been relatively responsive in making major material concessions. This was most clearly represented by a significant increase in social spending and a raft of prolabour legislation enacted under the administration of Hu Jintao (20022012). After decades of unrelenting marketization of health (Reddy, 2008), education (Mok, 2000; Mok et al., 2009), pensions (Frazier, 2010), and housing (Hsing, 2009; Huang, 2013; Logan et al., 2009), the 2000s witnessed increased government expenditures in each of these areas. Having actively pursued wage repression and labour market deregulation for years, the central government enacted a series of laws in 2008 intended to improve job security and material wellbeing for employees. Although fiercely opposed by employers, the landmark Labour Contract Law went into effect on 1 January of that year, and imposed new restriction on dismissals (among other things). In the wake of the global economic crisis, by the end of 2008 it seemed as though the high tide of marketization had subsided in China.

These shifts led Wang Shaoguang to argue that China was experiencing the 'double movement' just as Karl Polanyi would have expected - decommodification and a re-embedding of the economy have now become central to the state's political agenda (S. Wang, 2008). Cui Zhiyuan contends that the official rhetoric of 'market socialism' is in fact being realized in practice, and that the state is maintaining its central directing role in the economy (Cui, 2011, 2012). For a brief 
moment in 2010-12 (before the fall of Bo Xilai), there was open discussion of the relative merits of the Guangdong and Chongqing models - the former indicating greater economic and political liberalization, while the latter implied continued Party dominance but with greater emphasis on redistributive economic policies. Even if Bo Xilai has ended up in prison, it appears that the redistributive policies he enacted will persist, at least in Chongqing if not nationwide.

If the central state looked as if it was taking a cue from Polanyi and acting in the interest of society as a whole, local officials by and large maintained their strong alliance with capital. There have been numerous accounts of local governments being quite explicit with investors that they have no intention of strictly enforcing laws passed by the central government. This was a particularly major issue shortly after the passage of the Labour Contract Law in 2008, when many employers complained that the economic crisis was already hurting their profits. But the clearest example of a conscious undermining of the spirit, if not the letter, of the law can be seen in the massive increase of 'dispatch labour' since 2008. Dispatching refers to labour outsourcing in which employment and managerial relations are separated. This allows enterprises to avoid direct responsibility for their workers, and also makes it possible to skirt social insurance and severance payment regulations. According to the ACFTU, the total number of dispatched workers increased from 20 million to 60 million between 2008 and the end of 2010 (Jingji Guancha bao, 2011). Local governments often own labour dispatch companies directly or indirectly, and therefore have a direct interest in allowing this system to persist. Ironically, the Labour 
Contract Law appears to have served as a further catalyst for informalization of labour in China (Kuruvilla et al., 2011).

In a few instances, it has been the provincial rather than central government that has promoted legal reform. Following a failed attempt three years earlier, Guangdong province issued a draft version of a law to regulate collective negotiations. However, the law was clearly intended to constrain worker activism to the legal terrain and was roundly condemned by academics and labour NGOs alike. Among other problems, the law would for the first time explicitly ban work stoppages while negotiations are underway. Critics saw this as an attempt to provide a legal basis for cracking down on strikers, and argued that the current legal ambiguity of striking was preferable. It is also worth noting that during the period of public comment, there was no democratic mechanism for expressing the collective interests of workers - again, the state's activity was a response to labour unrest, but it was simultaneously indifferent to workers' opinions of this particular response. The consequence is that sympathetic but wholly unaccountable scholars and NGO officers were left to speak on behalf of workers. At the time of writing, this law remains in limbo.

Migrant workers were never mobilized during the passage of the Labour Contract Law and other labour laws. While awareness of legal rights appears to have improved in recent years and workers are likely to welcome the new rights they have gained, enforcement remains a major problem. It is likely that some kind of independent worker organization would be useful in ensuring legal compliance, as has been the case in other national contexts (Fine and Gordon, 2010). Workers are by and 
large left to seek legal enforcement as individuals, and adjudication is left up to a generally hostile local state. Thus, despite the emergence of a seemingly strong set of legal protections, Chinese workers and dominated classes more broadly are increasingly marked by anger and anxiety (Zheng, 2012). How can we come to terms with these seemingly contradictory trends?

\section{ALIENATED POLITICS}

My central claim is that migrant worker unrest is best characterized as a form of 'alienated politics'. It is worth emphasizing that I am not using 'alienation' in a humanistic sense and it does not refer to any sort of psychological condition among workers. Rather, alienated politics describes a situation in which countless cellular and depoliticized economic struggles result in major political shifts at the national level, while workers are unable to actively determine the form and content of this politics. The central state's efforts at depoliticization separates cause (worker unrest) from effect (new legislation), resulting in alienation between worker subjectivity and the class-level political object that workers themselves have produced. ${ }^{6}$ The state takes the threat of ungovernability (Piven and Cloward, 1977; Silver and Zhang, 2009) posed by expansive worker unrest quite seriously and has therefore responded by seeking to improve material conditions. Yet because of the structure of political space in China, most importantly the

6 I do not mean to suggest that localized resistance is somehow apolitical (or pre-political in Hobsbawm's [1959] terms). Rather, I am referring to alienation between worker subjects and the specific object of class-level politics. 
absence of worker representative organizations, such state activity is not a response to specifically articulated demands from below.

Rather, the consequence of alienated politics is that the central state appears to be, and in reality is, attempting to improve material conditions

Table 1. The Politics of State and Working Class in China

\begin{tabular}{lll}
\hline & Workers & State \\
\hline Central & Irrational/vulnerable & Paternalistic \\
Local & Rational/disruptive & Despotic \\
\hline
\end{tabular}

for workers of its own accord - i.e. paternalistically. ${ }^{7}$ The dirty work of capitalist growth is left to a despotic local government. As a result, the lawlessness and brutal exploitation that have been key features of the Chinese development model are enforced by the local state. It is the local, and not the central, government that calls in police to break a strike; that allows enterprises to illegally employ dispatch or forced student labour; and that will order unions to side with management during a labour conflict. When higher levels of the state actively intervene in labour disputes (more likely to happen in large-scale strikes in economically important sectors), they typically do not side completely with capital, but rather will seek to enforce compromise. This division of labour between different levels of the state allows for explosive growth and continued legitimacy of the centre in the midst of a depoliticized and fractured but expansive worker insurgency.

This political economy - referred to as 'decentralized legal

7 For a similar argument in the Latin American context, see Cohen (1982). 
authoritarianism' by Ching Kwan Lee (2007) - produces a particular kind of proletarian politics. As is true for the protesting farmers in Kevin O’Brien and Lianjiang Li's studies (2006), Chinese workers by and large proclaim fidelity to the law and to the central government. But from the state's perspective, worker unrest looks different depending on the vantage point (see Table 1). At the local level, it appears as rationaldisruptive. Rational in the sense that worker demands are economic and straightforward: the most common demands are related to wages; and disruptive in that strikes, road blockages, riots and other forms of resistance threaten social and economic stability at the local level. From the perspective of the centre, on the other hand, the working class appears as irrational-vulnerable. They are irrational in the sense that they have posed no political demands at the class level that the centre can respond to. The state is not deciding how to negotiate with a labour movement that is imposing a set of demands, but rather must figure out how to respond to a demand-less insurgency. The centre must be concerned with the stability of the system as a whole rather than the profitability of any particular firm. More recently, it has been concerned with increasing domestic consumption, and is therefore willing to form an indirect alliance with workers - as long as politics remains the strict domain of the Party. As a result, the central state views workers as a vulnerable group (ruoshi qunti in the official lexicon) and in need of succour.

The consequence of the Chinese state's dedication to political exclusion of the working class, as well as its capacity to enforce this, is that China has had a very different experience with labour politics than 
was the case in earlier industrializers. In essence, the Chinese working class has won major legislative victories without demanding anything. The consequence of this is that they have no sense of ownership of these victories, and enforcement remains tenuous. The central state hopes that labour relations can be determined by administrative fiat, without the emergence of independent organization. The irony is that depoliticization has precluded the emergence of a labour movement while simultaneously undermining the capacity of the state to reduce worker insurgency.

Even though the state has been able to contain unrest to the local level, there are still important political implications for the centre. Although the coercive measures necessary to stamp out worker organization are deployed at the local level, there is almost complete consensus throughout the state on this point. Indeed, it is the centre that maintains the categorical ban on independent worker organization, fearing it could threaten the stability of the system as a whole. There are many risks to the central government in pursuing this strategy. The first issue is already a reality: the huge increase in domestic repressive capacity (mentioned above), which is a significant economic burden. Although China is hardly democratic at present, it is possible to imagine a further deepening of repression, including stepped-up police violence and activist imprisonment. Second, and somewhat more speculatively, political exclusion of the working class from national politics can have the unintended consequence of politicizing worker demands (Seid- man, 1994). While there is scant evidence that this is happening in China at present, it is possible to imagine the development of citizenship-based 
demands, particularly from migrant workers. If such a movement were to occur in the current institutional vacuum, it could spell trouble for the central state. Finally, I have argued that alienated politics has allowed for the central state to intervene in labour strife strategically (either legislatively or in the resolution of particular conflicts) in a way that bolsters their legitimacy. It is an open question as to whether protesting workers actually believe in the benevolence of the centre, or if public displays of fidelity are merely strategic - and for the moment, the distinction is not that important since they are acting within the hegemonic framework. But the situation is dynamic, and there are scenarios in which worker discontent could scale up in a way that could be directly antagonistic to the central state. This would be more likely if migrant worker protest moves in a more Polanyian direction of demanding better access to social services such as education, healthcare, pensions and housing. Since migrants in all major cities face similar forms of exclusion, this kind of protest could quickly implicate higher levels of the state. In short, if worker unrest expanded beyond the factory to demands over reproduction, this would involve the stitching together of a broader constituency, thereby testing the limits of the central state's paternalism.

\section{CONCLUSION}

Is there a labour movement in China? My answer thus far has been no, but that does not mean that there are no labour politics. Worker unrest at the local level looks very Marxian in that workers are directly antagonistic to enterprise management in demanding higher wages, and they frequently come into direct conflict with the police and 
local state. Migrant workers are increasingly confident and willing to use radical tactics to attain their ends. But such activism has not resulted in an 'ever expanding union of the workers' as the Chinese state has proven astonishingly adept at depoliticiz-ing and cellularizing conflict. When we look at the central state, on the other hand, the situation looks much more Polanyian. Rather than unmediated antagonism, the central government has been moving towards class compromise in the economic sphere. 'Alienated politics' helps us to explain the gap between fierce antagonism at the local level and movements towards compromise and collaboration at the centre.

Thus far, the central state has been able ride out successive waves of insurgency, while ensuring continually high rates of growth. There are signs, however, that the strategy of depoliticization is reaching a limit. The government has been trying for a decade to 'rebalance' the economy, an effort that received increased attention after the economic crisis of 2008. Rebalancing implies, among other things, reducing intraand inter-regional inequality and increasing domestic consumption. There is broad agreement at the central level that getting people to spend more will require expanding social spending on health, education, pensions and housing (Chamon and Prasad, 2010), as well as allowing more rural migrants to settle permanently in the cities. But in the ten years since the central state began calling for readjustments, inequality has only grown and domestic consumption has remained flat. ${ }^{8}$ While there are a number of factors that have produced this outcome, a key

8 At the time of writing, consumption remains flat even as the country has maintained relatively strong overall growth. See: http://blogs.wsj.com/chinarealtime/2013/10/18/chinas-growthquickens-but-what-about-consumption/ 
element is the difficultyof enforcing class compromise in the absence of class organization. Rebalancing the economy requires overcoming forces in society that are tied to the current model of growth, and this cannot be accomplished through purely technocratic (depoliticized) means. A labour movement that has mobilized its rank and file in fighting for and winning new rights will likely have an interest and some capacity in fighting for the enforcement of those rights. In contemporary China, on the other hand, new rights are granted by the paternalistic state in a political environment in which local governments remain largely committed to the interests of employers. If the history of the twentieth century is any guide (which admittedly might not be the case), a more inclusive politics will be necessary to realize a more inclusive economy.

If alienated politics complicates the process of economic rebalancing, what then might occur in the event of a slowdown? While predicting political developments in China is a notoriously risky endeavour, the first possibility is simply that worker unrest declines. If labour-intensive manufacturing relocates either domestically or internationally, this would undercut workers' bargaining power. Indeed, there is already evidence that defensive struggles are on the rise in the Pearl River Delta as higher costs have pushed capital to move elsewhere. ${ }^{9}$ The state would likely be able to ride out an increase in defensive struggles, but would then be faced with the question of what to do with millions of unemployed migrants. Economic and political elites would lock in their advantages, and a transition to a higher value-

9 For a non-representative sample, see the media reports collected here: http://www. numble.com/PHP/mysql/clbmape.html 
added economy would be frustrated.

Another possibility is that a slowdown would give increased impetus for the state to make efforts at building a more substantive corporatist arrangement. Although this would entail political risks for the centre, as it would demand some delegation of authority to non-state actors, it would likely help redirect a greater share of wealth to employees, thereby helping to encourage the transition to a consumption-based economy. A slowdown in growth could increase the centre's urgency in bringing about such a transformation in the structure of the economy.

A final possibility is that slackening growth leads to increased worker unrest that is able to overcome state repression (in its various guises) to build durable organized networks of resistance. This would require reaching some 'tipping point' in which a large enough volume of people would have to be affected simultaneously. This seems quite unlikely at present. However, it is worth considering how new patterns of migration and land reform in the countryside may impact these dynamics. In previous years, collective rural land has acted as a safety valve to defuse labour struggles among migrant workers in the city. Recently, more migrants have expressed a desire to stay in the city. Additionally, with ongoing land expropriation and more experiments with commodification of rural land, it is likely that an increasing share of migrant workers will not have any land to return to. By diminishing the viability of this safety valve, the state may inadvertently increase the intensity of urban labour struggles during an economic downturn.

If the labour movement is in fact 'historically superseded' 
(Castells, 1997: 360), China provides clear evidence that worker resistance is alive and well. But Castells may still be correct: there is no labour movement in China, but rather a dispersed and ephemeral insurgency. Moreover, evidence is emerging that some of these political dynamics may not be limited to China. Vietnam has many close parallels, where the state has maintained a categorical ban on independent worker organization, while managing to politically contain frequent and highly militant wildcat strikes in export processing zones (A. Chan, 2011). Even in democratic South Africa, Shauna Mottiar has described service delivery protests as, 'popping up and bursting onto the scene only to rapidly subside', and argues that, 'Local service delivery demands have won limited concessions and tend to consolidate support for the ANC rather than igniting a movement against ANC neoliberal policy' (Mottiar, 2013: 607). The concept of alienated politics helps to highlight both that localized and seemingly apolitical protest can have major consequences in the aggregate, but also that the separation of cause from effect can bolster the legitimacy of the centre. A labour movement must have the capacity to formulate, secure and enforce political demands. The Chinese state has thus far been able to prevent such a force from emerging, and will likely continue to do everything in its capacity to maintain the status quo. But negotiating over rationally articulated demands from an organized opponent may eventually seem preferable to grasping at the shadow of generalized insurgency.

\section{REFERENCES}

Beck, U. (1992) Risk Society: Towards a New Modernity. London: Sage Publications. 
Biekart, K. and A. Fowler (2013) 'Transforming Activisms 2010+:

Exploring Ways and Waves', Development and Change 44(3): 527-46.

Buckley, C. (2012) 'China Domestic Security Spending Rises to \$111 Billion'. Reuters, 5 March.

http://www.reuters.com/article/2012/03/05/us-china-parliamentsecurity-idUSTRE 82403J20120305

Castells, M. (1997) The Power of Identity. Malden, MA: Blackwell.

Chamon, M.D. and E.S. Prasad (2010) 'Why are Saving Rates of Urban Households in China Rising?', American Economic Journal:

Macroeconomics 2(1): 93-130.

Chan, A. (1993) 'Revolution or Corporatism? Workers and Trade Unions in Post-Mao China', The Australian Journal of Chinese Affairs 29: 31-61.

Chan, A. (2011) 'Strikes in China's Export Industries in Comparative Perspective', The China Journal 65: 27-51.

Chan, C.K.-C. (2010) The Challenge of Labour in China: Strikes and the Changing Labour Regime in Global Factories. London: Routledge.

Chan, C.K.-C. (2012) 'Class or Citizenship? Debating Workplace Conflict in China', Journal of Contemporary Asia 42(2): 308-27.

Chan C.K.-C. (2014) 'Constrained Labour Agency and the Changing Regulatory Regime in China', Development and Change 45(4). DOI: 10.1111/dech.12104.

Chan, C.K.-C. and N. Pun (2009) 'The Making of a New Working Class? A Study of Collective Action of Migrant Workers in South China', China Quarterly 198: 287-303. 
Chan, J. and N. Pun (2010) 'Suicide as Protest for the New Generation of Chinese Migrant Workers: Foxconn, Global Capital, and the State', The Asia-Pacific Journal 8(37): 2-10.

Chan, K.W. (2009) 'The Chinese Hukou System at 50', Eurasian Geography and Economics 50(2): 197-221.

Chan, K.W. (2010) 'The Global Financial Crisis and Migrant Workers in China: "There is No Future as a Labourer; Returning to the Village has No Meaning"', International Journal of Urban and Regional Research 34(3): 659-77.

Chan, K.W. and W. Buckingham (2008) 'Is China Abolishing the Hukou System?', China Quarterly 195: 582-606.

Chen, F. (2007) 'Individual Rights and Collective Rights: Labor's Predicament in China', Communist and Post-Communist Studies 40: 5979.

Chen, F. (2009) 'Union Power in China: Source, Operation, and Constraints', Modern China 35: 662-89.

Chen, F. (2010) 'Trade Unions and the Quadripartite Interactions in Strike Settlement in China', The China Quarterly 201: 104-24.

Chen, F. and X. Xu (2012) "'Active Judiciary": Judicial Dismantling of Workers' Collective Action in China', The China Journal 67: 87-108.

Chen, X. (2013) 'The Rising Cost of Stability', Journal of Democracy 24(1): 57-64.

Cohen, Y. (1982) “"The Benevolent Leviathan": Political Consciousness among Urban Workers under State Corporatism', The American Political 
Science Review 76(1): 46-59.

Cui, Z. (2011) 'Partial Intimations of the Coming Whole: The Chongqing Experiment in Light of the Theories of Henry George, James Meade, and Antonio Gramsci', Modern China 37(6): 646-60.

Cui, Z. (2012) 'Making Sense of the Chinese "Socialist Market Economy": A Note', Modern China 38(6): 665-76.

Dickson, B.J. (2003) Red Capitalists in China: The Party, Private Entrepreneurs, and Prospects for Political Change. Cambridge: Cambridge University Press.

Fine, J. and J. Gordon (2010) 'Strengthening Labor Standards Enforcement through Partnerships with Workers' Organizations', Politics \& Society 38(4): 552-85.

Fravel, M.T. (2011) 'Economic Growth, Regime Insecurity, and Military Strategy: Explaining the Rise of Noncombat Operations in China', Asian Security 7(3): 177-200.

Frazier, M. (2010) Socialist Insecurity: Pensions and the Politics of Uneven Development in China. Ithaca, NY: Cornell University Press.

Friedman, E. (2012) 'Getting Through the Hard Times Together? Chinese Workers and Unions Respond to the Economic Crisis', Journal of Industrial Relations 54(4): 459-75.

Friedman, E. (2013) 'Insurgency and Institutionalization: The Polanyian Countermovement and Chinese Labor Politics', Theory and Society 42(3): 295-327.

Friedman, E. (2014) Insurgency Trap: Labor Politics in Postsocialist China. 
Ithaca, NY: Cornell University Press.

Friedman, E. and C.K. Lee (2010) 'Remaking the World of Chinese Labour: A 30-Year Retrospective', British Journal of Industrial Relations 48(3): 507-33.

Gallagher, M. (2005) Contagious Capitalism: Globalization and the Politics of Labor in China. Princeton, NJ: Princeton University Press.

Guo, Y. (2009) 'Farewell to Class, except the Middle Class: The Politics of Class Analysis in Contemporary China', The Asia-Pacific Journal 26(2). http://www.japanfocus.org/-Yingjie- Guo/3181

Hobsbawm, E. (1959) Primitive Rebels. New York: Norton.

Hsing, Y. (2009) The Great Urban Transformation: Politics of Land and Property in China. Oxford: Oxford University Press.

Huang, Y. (2013) 'Low-income Housing in Chinese Cities: Policies and Practices', The China Quarterly 212: 941-64.

Hurst, W. (2009) The Chinese Worker after Socialism. Cambridge:

Cambridge University Press.

Jingji Guancha bao (2011) 'Quanwei baogao cheng "laowu paiqian” da 6000 wanren quanzong jianyi xiugai "laodong hetongfa"' ['Authoritative Report Claims "Labour Dispatch" Has Reached 60 Million People, ACFTU Suggests Revisions to Labour Contract Law'], Jingji Guancha bao 25 February. http://www.eeo.com.cn/eeo/iigcb/2011/02/28/194384.shtml (accessed 25 June 2013).

Kuruvilla, S., C.K. Lee and M.E. Gallagher (2011) From Iron Rice Bowl to Informalization: Markets, Workers, and the State in a Changing China. 
Ithaca, NY: ILR Press.

Lee, C.K. (2002) 'From the Specter of Mao to the Spirit of the Law: Labor Insurgency in China', Theory and Society 31: 189-228.

Lee, C.K. (2007) Against the Law: Labor Protests in China's Rustbelt and Sunbelt. Berkeley, CA: University of California Press.

Lee, C.K. and Y. Zhang (2013) 'The Power of Instability: Unraveling the Microfoundations of Bargained Authoritarianism in China', American Journal of Sociology 118(6): 1475-508.

Logan, J.R., Y. Fang and Z. Zhang (2009) 'Access to Housing in Urban China', International Journal of Urban and Regional Research 33(4): 91435.

Marx, K. (1994) 'The Communist Manifesto', inL.H. Simon (ed.) Karl Marx: Selected Writings, pp. 157-86. Indianapolis, IN: Hackett.

Mok, K.H. (2000) 'Marketizing Higher Education in Post-Mao China', International Journal of Educational Development 20(2): 109-26.

Mok, K.H., Y.C. Wong and X. Zhang (2009) 'When Marketisation and Privatisation Clash with Socialist Ideals: Educational Inequality in Urban China', International Journal of Educational Development 29(5): 505-12. Mottiar, S. (2013) 'From "Popcorn" to "Occupy": Protest in Durban, South Africa',Development and Change 44(3): 603-19.

Nathan, A.J. (2003) 'China's Changing of the Guard: Authoritarian Resilience', Journal of Democracy 14(1): 6-17.

O’Brien, K. and L. Li (2006) Rightful Resistance in Rural China. Cambridge: Cambridge University Press. 
Ost, D. (2000) 'Illusory Corporatism in Eastern Europe: Neoliberal Tripartism and Postcommunist Class Identities', Politics \& Society 28(4): 503-30.

Perry, E.J. (2007) 'Studying Chinese Politics: Farewell to Revolution?', The China Journal 57: 1-22.

Piven, F.F. and R. Cloward (1977) Poor People's Movements: Why They Succeed, How They Fail. New York: Vintage.

Pun, N. and C.K.-C. Chan (2008) 'The Subsumption of Class Discourse in China', Boundary 235(2): 75-91.

Pun, N. and J.W. Chan (2012) 'Global Capital, the State, and Chinese Workers: The Foxconn Experience', Modern China 38(4): 383-410.

Reddy, S. (2008) 'Death in China: Market Reforms and Health', International Journal of Health Services 38(1): 125-41.

Seidman, G. (1994) Manufacturing Militance: Workers' Movements in Brazil and South Africa, 1970-1985. Berkeley, CA: University of California Press.

Silver, B.J. and L. Zhang (2009) 'China as an Emerging Epicenter of World Labor Unrest', in H. Hung (ed.) China and the Transformation of Global Capitalism, pp. 174-87. Baltimore, MD: Johns Hopkins University Press.

Solinger, D.J. (2001) 'Why We Cannot Count the "Unemployed"', The China Quarterly 167: 671-88.

Solinger, D.J. (2009) States' Gains, Labor's Losses: China, France, and Mexico Choose Global Liaisons, 1980-2000. Ithaca, NY: Cornell University Press. 
Tronti, M. (1971) Operai e Capitale [Workers and Capital]. Turin: Einaudi.

Wang, H. (2006) 'Depoliticized Politics, from East to West', New Left Review 41: 29-45.

Wang, H. (2009) The End of the Revolution: China and the Limits of Modernity. London: Verso.

Wang, S. (2008) 'The Great Transformation: The Double Movement in China', boundary 2 35(2): 15-47.

Wright, T. (2010) Accepting Authoritarianism: State-society Relations in China's Reform Era. Stanford, CA: Stanford University Press.

Yan, Y. (2010) 'The Chinese Path to Individualization', The British Journal of Sociology 61(3): 489-512.

Zhan, S. (2011) 'What Determines Migrant Workers' Life Chances in Contemporary China? Hukou, Social Exclusion, and the Market', Modern China 37(3): 243-85.

Zheng, Y. (2012) 'China in 2011: Anger, Political Consciousness, Anxiety, and Uncertainty', Asian Survey 52(1): 28-41.

Zhu, Y. (2011) “"Performance Legitimacy” and China's Political Adaptation Strategy', Journal of Chinese Political Science 16(2): 123-40. 
Eli Friedman is Assistant Professor of International and Comparative Labor at Cornell University's ILR School, Ithaca, NY, USA. He is the author of the recently published Insurgency Trap: Labor Politics in Postsocialist China, and has ongoing interests in labour, urbanization, education and social movements. He can be reached by e-mail at: edf48@cornell.edu. 